\title{
How Competitive Is Hong Kong Against its Competitors? An Econometric Study
}

\author{
Gang $\mathrm{Li}^{\mathrm{a}}$, Haiyan Song ${ }^{\mathrm{b}}$, Zheng $\mathrm{Cao}^{\mathrm{a}}$ and Doris Chenguang $\mathrm{Wu}^{\mathrm{c}, *}$
}

a. School of Hospitality and Tourism Management, University of Surrey, Guildford GU2 7XH, UK

b. School of Hotel and Tourism Management, The Hong Kong Polytechnic University, Hong Kong

c. Sun Yat-sen Business School, Sun Yat-sen University, Guangzhou, China

\section{Highlights}

- The AIDS model is used to examine Hong Kong's competitiveness as a tourist destination in comparison with its competitors.

- The empirical findings show that a destination's competitiveness should be examined from a market-specific perspective.

- Hong Kong is more competitive than Macau in terms of its ability to attract Australian and mainland Chinese tourists.

- Singapore and South Korea are more competitive than Hong Kong as suggested by the price elasticities.

\begin{abstract}
This study utilizes almost ideal demand system (AIDS) models to examine Hong Kong's competitiveness as an international tourist destination in comparison with its competitors. The empirical findings of the study shed new light on the destination competitiveness literature and demonstrate that a destination's competitiveness should be examined from a market-specific perspective. The results also suggest that Hong Kong is more competitive than Macau, particularly in terms of its ability to attract Australian and mainland Chinese tourists, while price elasticity calculations suggest Singapore and South Korea are more competitive than Hong Kong.
\end{abstract}

Keywords: competitiveness, system model, tourism demand, Hong Kong

\section{Introduction}

The notion of destination competitiveness stems from that of "competitiveness" in the international economics and international business literature. One of a variety of similar definitions of competitiveness is "the capacity of businesses, industries, regions,

\footnotetext{
* Corresponding author. E-mail addresses: g.li@surrey.ac.uk (G. Li), haiyan.song@polyu.edu.hk (H. Song), zheng.cao@surrey.ac.uk (Z.Cao), wuchenguang@gmail.com (D.C.Wu).

To cite the paper:

Li G, Song H, Cao Z, Wu DC. (2013). How competitive is Hong Kong against its competitors? An econometric study. Tourism Management, 36 (1), pp. 247-256. doi: 10.1016/j.tourman.2012.11.019
} 
nations or supernational associations exposed, and remaining exposed, to international competition to secure a relatively high return on the factors of production and relatively high employment levels on a sustainable basis" (European Commission, 1994, p. 17). In the context of tourism, destination competitiveness can be defined as "the destination's ability to create and integrate value-added products that sustain its resources while maintaining market position relative to competitors" (Hassan, 2000, p. 239).

As with the general concept of competitiveness, destination competitiveness is complex and multi-dimensional with the economic dimension being the core. Hence, destination competitiveness analysis would not be valid if it did not address the economic concern. It is commonly held that destination competitiveness is essentially linked to visitor expenditure. As stated by Ritchie and Crouch (2003, p. 2), "what makes a tourism destination truly competitive is its ability to increase tourism expenditure, to increasingly attract visitors..." In particular, a destination's ability to attract tourist expenditure (reflected by its changes) in comparison with that of its competitors should be treated as the key issue, at least from the economic perspective. Only when it is able to convert the advantageous positions of some indicators into tourism revenues can a destination be regarded as competitive. For instance, a lower price level does not necessarily lead to higher economic returns. If the demand for a destination is price inelastic, a price reduction strategy is unlikely to boost tourism revenues of the destination. In this regard, demand elasticities are well suited to measuring destination competitiveness.

Given the difficulty in investigating a whole range of dimensions of destination competitiveness in one empirical study, and in recognition of the core position of the economic dimension, the current study aims to examine Hong Kong's competitiveness from one specific perspective: economic returns (i.e., tourist expenditures) based on a demand elasticity analysis. The novelty of this study is the use of the almost ideal demand system (AIDS) model in competitiveness assessment, which has not been seen in the literature. Although a variety of indicators have been proposed to define or measure competitiveness, many of them act as inputs in competitions and only imply the competitiveness to a certain extent. A proper link between the inputs and outputs (returns) is usually missing. Drawing rigorous grounding from consumer demand theory, the AIDS model is well placed to capture tourists' budget changes, and thus to obtain insights into the economic performance of each destination in different scenarios. In the present study competitiveness is investigated in relation to demand elasticities, which connect the inputs and outputs of competition. For each origin country, elasticities of demand for Hong Kong and its key competitors are estimated and the results are compared across all the origins involved. This allows one to examine how successful a destination is in attracting tourism demand against its competitors. Furthermore, the current study also accounts for the causal relationship between price and competitiveness with the concept of price tolerance, i.e. the maximum price increase that the customers are willing to tolerate before switching to substitute products. It is noted by Croes (2011) that clear causal links between the indicators and competitiveness tend to be lacking in some studies. Price tolerance, well tested empirically in mainstream economics, provides a well-grounded perspective to approach this issue. 


\section{Literature Review}

\subsection{Destination Competitiveness}

Various perspectives and alternative approaches have been adopted in the literature of destination competitiveness analyses. The most comprehensive work on overall tourism destination competitiveness was undertaken by Crouch and Ritchie (see, for example, Crouch \& Ritchie, 1994 and Richie \& Crouch, 2003). They developed a conceptual model of overall destination competitiveness that incorporated such key elements as core and supporting resources, destination management, policy, planning and development, and qualifying and amplifying determinants. The Crouch-Ritchie model has provided a useful conceptual framework for various empirical studies such as d'Harteserre (2000), Go and Govers (2000) and Kim, Guo, and Agrusa (2005). Given the complexity of the conceptual model, many of these empirical studies are based on descriptive analyses only, or focus on selected indicators to measure each of the multiple dimensions of destination competitiveness. It is rather difficult to exercise advanced statistical or econometric analyses under such a complex conceptual framework.

Instead of taking a multi-dimensional or multi-perspective approach, a number of other studies focused on a particular dimension or a particular sector of tourism, such as Bueno (1999), Cizmar and Seric (1999), Hassan (2000), Osmanagic-Bedenik (1999), Pechlaner (1999) and Prideaux (2000). The study by Dwyer, Forsyth, and Rao (2000) had a particular focus on price competitiveness. They developed an index to measure Australia's price competitiveness in comparison with that of 18 competitors in a number of key source markets, whereas most other competitiveness analyses are not concerned with the origin country/region. However, Dwyer et al. (2000) did not examine how price competitiveness may affect the economic returns of the destination (i.e., tourist expenditure or tourism revenue). As discussed above, it is the effects of prices on a destination's economic returns that ultimately matter. With regard to the research method, this study followed multiple steps to construct price competitiveness indices, and statistical or econometric techniques were not applied.

The AIDS model developed by Deaton and Muellbauer (1980) is an appropriate econometric approach for such a purpose. It is able to examine how consumers allocate their expenditure among a bundle of products to maximize their utility. In the specific context of tourism, this approach can be used to analyze the impacts of relative prices in different destinations on the allocation of tourist expenditure and on the interdependence among alternative destinations, especially when these destinations are competitors. Therefore, the AIDS model is useful for destination competitiveness analysis. Over the past decade, the AIDS model has been gaining increasing popularity. Its applications include the studies by Cortés-Jiménez, Durbarry and Pulina (2009), De Mello, Pack and Sinclair (2002), Divisekera (2003), Li, Song, and Witt (2004 and 2006), Lyssiotou (2000), Mangion, Durbarry, and Sinclair (2005), Papatheodorou (1999) and Syriopoulos and Sinclair (1993). Using a relevant dataset to the current study, $\mathrm{Wu}, \mathrm{Li}$ and Song (2011) analyzed Hong Kong inbound tourists' consumption pattern for different tourism products (i.e., shopping, accommodation, meals, and others) and investigated the impacts of price changes on how these inbound tourists allocated their budgets among different products that they purchased. 
Despite the popularity of the AIDS model, few have realized its potential application to competitiveness assessment. To the best of our knowledge, the study by Mangion et al. (2005) is the only one that addressed the issue. They initially examined price competitiveness at the macro-level using the LAIDS model. The results were then complemented by estimating the characteristics of package holidays using a hedonic pricing model. The results of the two-stage analysis were ultimately combined to decide how the provision of different tourism product characteristics contributes to increases in the price of the product and further affects tourism demand. However, because the analysis focused solely on the demand by a single source market (i.e., the UK) for selected Mediterranean destinations, the findings did not provide any insight into the relative competitiveness of a particular destination as perceived in a number of source markets. In other words, their study did not address the issue that a destination is likely to present different levels of competitiveness as far as different source markets are concerned. A more comprehensive analysis can be conducted by using a series of LAIDS models, each of which refers to one selected key source market and includes the destination concerned along with a number of its competitors in the demand system. Considering the competitiveness of Hong Kong as an international destination, the present study uses this approach to bridge the widening gap in the destination competitiveness literature.

\subsection{Tourism in Hong Kong and the Competition}

Tourism is one of the four pillar industries in the Hong Kong economy, registering a robust growth over the past decade. With rich and diverse tourism resources on offer, Hong Kong has consistently been ranked among the top destinations in Asia, attracting visitors from around the world. According to The Travel \& Tourism Competitiveness Report 2011 (Blanke \& Chiesa, 2011), Hong Kong was overall ranked $12^{\text {th }}$ out of 135 destinations and the second in Asia. However, to maintain its competitive advantages and realize sustainable success over the long run, Hong Kong will be obliged to respond to increasing challenges from its neighboring competitors in the region. According to The Travel \& Tourism Competitiveness Report 2011, Hong Kong's key competitors include Singapore, ranked top in the region and the $10^{\text {th }}$ in the world, followed by Japan (the third in Asia and $22^{\text {nd }}$ in the world) and South Korea (the fourth in Asia and $32^{\text {nd }}$ in the world). In addition, although not included in the above competitiveness report, Macau is generally recognized as a key competitor of Hong Kong given its geographic location and cultural similarity. These competitors commonly recognize the importance of tourism in their economic developments and compete between each other in this front. For example, the Singaporean government has been promoting medical tourism since 2003. It also deregulated casinos and saw two magnificent casino resorts opened in 2010. Enright and Newton (2004, p.782) argued that, "given its comparable role as an economic centre, a gateway for part of the region, and similar size, it was not surprising that Singapore would emerge as Hong Kong's principal competitor." South Korea, especially its capital city Seoul, has great potential to rival Hong Kong in both business tourism and leisure tourism with a mixture of commercial and cultural attractions. Seoul is also an Asian hub for medical tourism and is renowned for its plastic surgery industry. Despite being virtually dominated by its gambling industry, Macau has recently come to realize the necessity of promoting business tourism and the MICE industry to develop itself as "...a comprehensive and relaxing holiday destination, luring different kinds of tourists with large varieties of leisure activities and entertainment" (Pao, 2004, p. 92). In 
empirical tourism demand models, Singapore, South Korea and Macau are often regarded as substitute destinations of Hong Kong, and their price levels are used to form the aggregate substitute price for Hong Kong's tourism (for example, Song et al., 2010; Song \& Witt, 2006; Song, Wong, \& Chon, 2003). Japan, especially Tokyo, is also noted as a key competitor of Hong Kong by Enright and Newton (2004), along with other major cities in Asia, such as Bangkok and Shanghai. However, due to data unavailability ${ }^{*}$, these competitors, at either the city or country level, are excluded from the present study regrettably. Thus Singapore, South Korea (instead of Seoul due to the data constraint) and Macau are included as the overall key competitors for this Hong Kong competitiveness analysis. In the following empirical analysis, the relative competitiveness of Hong Kong against these key competitors in each of the selected origin markets will be examined respectively.

\section{Methodology}

\subsection{The LAIDS Model}

The LAIDS model relates to a multi-stage budgeting approach and focuses on explaining variations in the share of tourism expenditure. In our specification, tourists from a given source market first allocate their total expenditure between the four destinations concerned (i.e., Hong Kong, Macau, Singapore and South Korea) and other destinations. Tourists then decide on the budget share allocated to each of the four destinations. The current investigation examines the last stage of budgeting process and is aimed at capturing the interrelationship among levels of demand for the four destinations by tourists from a particular source market.

In brief, the LAIDS model attributes variations in the budget share of good/service $i$ to the logarithm of prices and total real expenditure in the following static form:

$$
w_{i t}=a_{i}+\sum_{j} \gamma_{i j} \ln p_{j t}+b_{i} \ln \left(x_{t} / P_{t}^{*}\right)
$$

where $t$ represents time $\mathrm{t}, w_{i t}$ is the budget share of the $i^{\text {th }} \mathrm{good} /$ service, $p_{j t}$ is the price of the $j^{\text {th }} \mathrm{good} / \mathrm{service}$ defined as $p_{j t}=\frac{C P I_{j t} / E X_{j t}}{C P I_{\text {orig.t. }} / E X_{\text {orig.t. }}}, x_{t}$ is total expenditure on all products in the system, $P_{t}^{*}$ is the aggregate price index, and $x_{t} / P_{t}^{*}$ is thus real total expenditure. Specifically, $P_{t}^{*}$ is Stone's price index defined as $\ln P_{t}^{*}=\sum w_{i t} \ln p_{i t}$ (Deaton \& Muellbauer, 1980; Li et al., 2004). In this study, $i$ and $j$ represent the four destinations constituting a demand system. It should be noted that travel cost is not included as a separate price variable, because the LAIDS specification requires one overall price for each destination. The consumer price index (CPI) adjusted by the relevant exchange rate is regarded as an appropriate proxy of the overall price of a destination and is widely used in previous studies (Song, Wong, \& Chon, 2003). In addition, the data of tourist expenditure $\left(x_{t}\right)$ normally cover tourists' spending at the destination and exclude the expenses for travelling from the origin to the destination. Hence international travel cost is excluded from the LAIDS analysis.

\footnotetext{
${ }^{*}$ Unlike data on tourist arrivals, which are consistently reported by the tourism authorities of most countries/regions, tourist expenditure data from open source are limited.
} 
In accordance with the theoretical properties of demand theory, several restrictions are imposed on the parameters of the LAIDS model. The adding-up restrictions require that $\sum_{i=1}^{n} a_{i}=1, \sum_{i=1}^{n} \gamma_{i j}=0$ and $\sum_{i=1}^{n} b_{i}=0$, restrictions that allow for all budget shares to sum to unity. Homogeneity requires that $\sum_{j} \gamma_{i j}=0$, which assumes that the consumer does not exhibit money illusion. Symmetry requires that $\gamma_{i j}=\gamma_{j i}$ to take the consistency of consumers' choices into account. Negativity requires the matrix of substitution effects to be negatively semi-definite and implies that all compensated ownprice elasticities must be negative ( $\mathrm{Li}$ et al., 2004). To test for homogeneity and symmetry restrictions, two sample size-corrected statistics developed by Court (1968) and Deaton (1974) are used instead of employing conventional methods such as the Wald test, the likelihood ratio test or the Lagrange multiplier test, which may be biased towards rejection of the null hypothesis (Li et al., 2004).

As often noted in the literature such as Edgerton et al. (1996), the static LAIDS model often renders some misspecification problems and failures of restriction tests. The elasticity estimates based on the static AIDS models are inevitably biased. Therefore it is necessary to incorporate dynamic components into the LAIDS model. A dynamic LAIDS is able to deal with such problems as habit persistence, adjustment costs, imperfect information and incorrect expectation, which prevent consumers from adjusting their short-run expenditure instantaneously in response to price and income changes (Anderson \& Blundell, 1983; Duffy, 2003; Li et al., 2004). The error correction form of the LAIDS model (i.e., EC-LAIDS) is the most common dynamic specification in the literature, and it is specified as:

$$
\Delta w_{i t}=c_{i}+\delta_{i} \Delta w_{i t-1}+\sum_{j} \gamma_{i j} \Delta \ln p_{j t}+b_{i} \Delta \ln \left(x_{t} / P_{t}^{*}\right)+\lambda_{i} E C T_{i t-1}+\varphi_{i} \text { Dummies }
$$

where $\Delta$ refers to the difference operator and $E C T_{i t-1}$ refers to the error correction term that measures the feedback effect and is estimated from the corresponding cointegration equation. The dummy variables capture the effects of one-off events. In this study dummy variables include D97 representing the Asian financial crisis of 1997 and DSARS representing the SARS epidemic in 2003. D97 takes the value of 1 in 1997 and 0 otherwise, other than in the demand systems of Japan and Taiwan, where it equals 1 in both 1997 and 1998 to capture the longer term effects of the crisis; DSARS takes the value of 1 in 2003 and 0 otherwise.

\subsection{Model Estimation}

The estimation starts with the test for the cointegration relationship between the share of tourism expenditure and its economic determinants. All variables are first tested for unit roots using the augmented Dickey-Fuller (ADF) test and Phillips-Perron (PP) test. Since the ADF test and PP test may have low power in the cases of small samples, the more powerful Dickey-Fuller GLS test proposed by Elliott, Rothenberg, and Stock (1996) is also employed. Consistently found by the three tests, all variables are integrated of order one, i.e., I(1). The long-run equilibrium relationship among the variables in each equation of the LAIDS model (Eq. 1) is then examined according to the Engle-Granger two-stage approach. Where necessary, the dummy variables are included in the long-run equations for the cointegration test (Han, Durbarry, \& Sinclair, 2006; Papatheodorou, 1999). The results confirm the existence of cointegration for all 
equations in each demand system at the 5\% significance level. The residuals from these cointegration regressions are calculated and enter the EC-LAIDS estimation as the ECT terms.

The unrestricted EC-LAIDS model (Eq. 2) for each demand system is constructed and estimated using the widely accepted Zellner's (1962) iterative seemingly unrelated regressions (SUR) method. Because the sum of all expenditure shares in the LAIDS model is equal to unity, the residuals variance-covariance matrix is singular. The usual solution is to delete an equation from the system, and in this study the equation for South Korea is dropped. Parameters in the deleted equation can be inferred easily in accordance with the adding-up restrictions. When the unrestricted EC-LAIDS model is estimated, the restrictions of homogeneity and symmetry are imposed one by one and the model is re-estimated. Restriction tests are then conducted to check whether the properties of demand theory hold in this empirical study.

As discussed in the literature review, the interest of the present study is to evaluate the destination's competitiveness based on the demand elasticity analysis. Short-run expenditure and price elasticities are thus calculated from the estimated EC-LAIDS models and they have standard implications. The expenditure elasticity $\left(\varepsilon_{i x}\right)$, which measures the sensitivity of demand in response to changes in expenditure, is calculated as $\varepsilon_{i x}=1+b_{i} / \overline{w_{i}}$, where $\bar{w}_{i}$ refers to the average budget share over the sample period. The uncompensated own-price elasticity $\left(\varepsilon_{i i}\right)$ and cross-price elasticity $\left(\varepsilon_{i j}\right)$ measure the extent to which a change in the price of one product affects the demand for the same and other products, with total expenditure and other prices held constant. They are given by $\varepsilon_{i i}=\gamma_{i i} / \overline{w_{i}}-b_{i}-1$ and $\varepsilon_{i j}=\gamma_{i j} / \overline{w_{i}}-b_{i} \overline{w_{j}} / \overline{w_{i}}$, respectively. In the same way, compensated price elasticities $\left(\varepsilon^{*}{ }_{i i}\right.$ and $\varepsilon_{i j}^{*}$ ), which measure the effects of prices on demand assuming real expenditure $\left(x / P^{*}\right)$ is constant, are calculated as $\varepsilon_{i i}^{*}=\gamma_{i i} / \overline{w_{i}}+\overline{w_{i}}-1$ and $\varepsilon_{i j}^{*}=\gamma_{i j} / \overline{w_{i}}+\overline{w_{j}}$, respectively.

\subsection{Data Description}

Six of Hong Kong's key source markets-Australia, mainland China, Japan, Taiwan, the UK and the USA - are chosen to investigate the competition between Hong Kong and its rivals in Asia. Annual data on tourist expenditure by source market and destination are collected from either the websites or statistical yearbooks of tourism authorities or national bureaus of statistics of the countries/regions concerned. The expenditure data are then converted into per capita figures and the share of expenditure by tourists from a particular source market in each of the destinations concerned is calculated. Subject to data availability, the sample period examined in this study covers a relatively short time span from 1991 to 2008 (other than for Australia and mainland China, for which the sample period is from 1995 to 2008). Figure 1 shows the dynamics of expenditure per capita over the sample period. 
Figure 1. Expenditure Per Capita of Major Source Markets of Hong Kong and Its Competitors

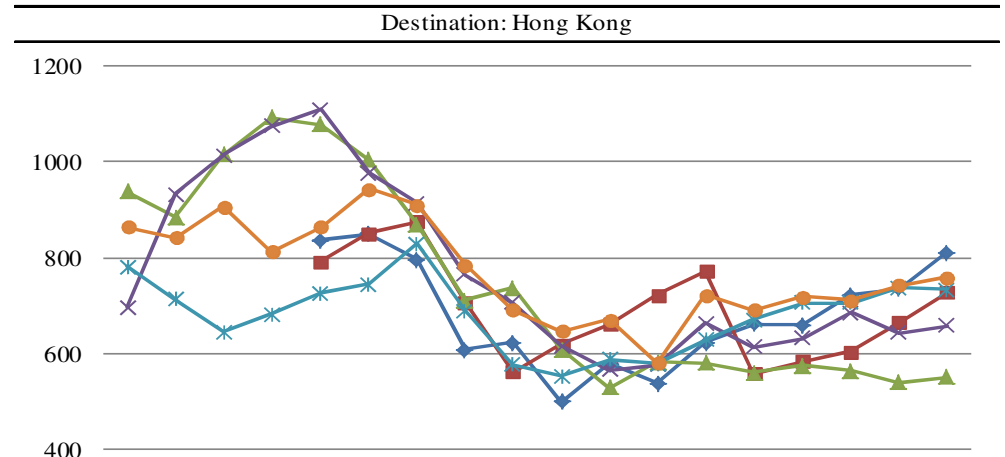

200

0

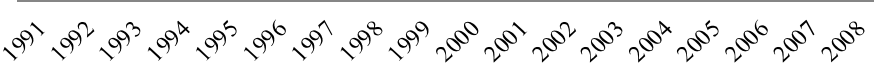

$\leadsto$ Australia $\rightarrow$ China $\multimap$ Japan $\leftarrow$ Taiwan $\multimap$ UK $\multimap$ USA

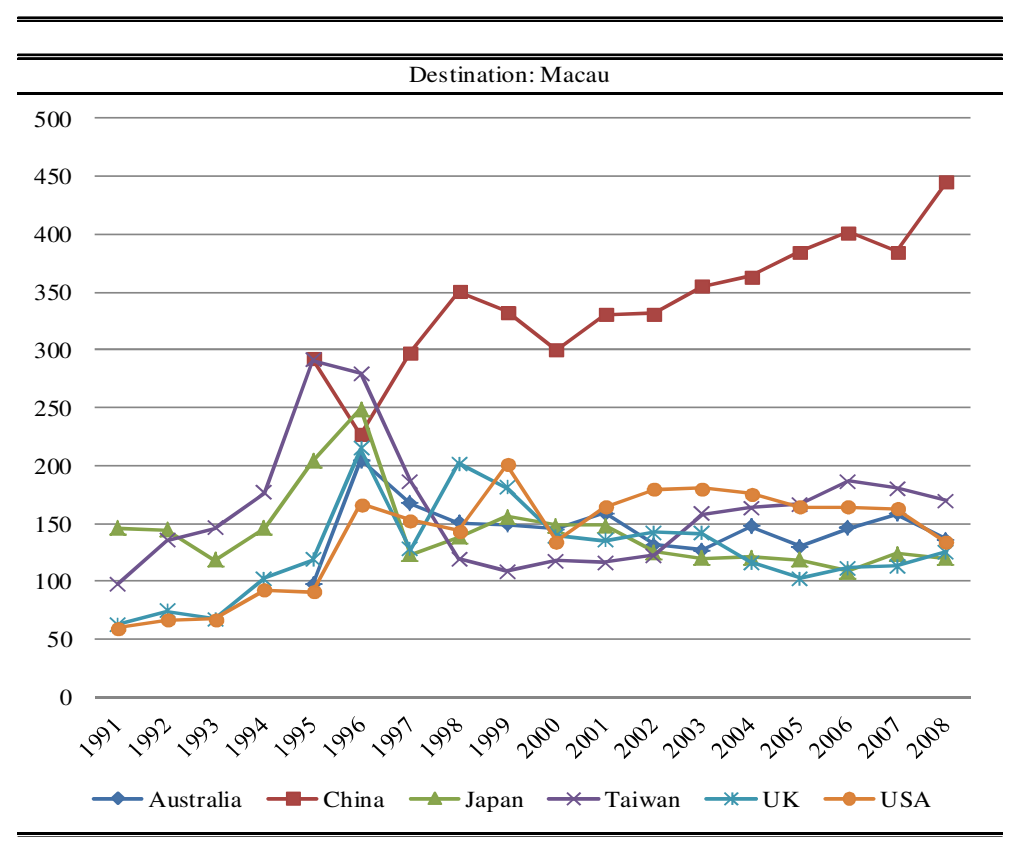

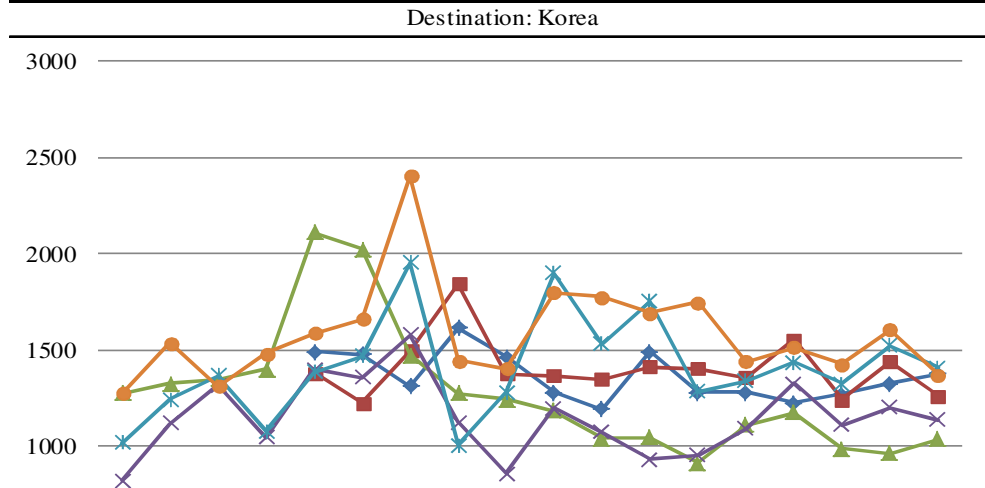

500

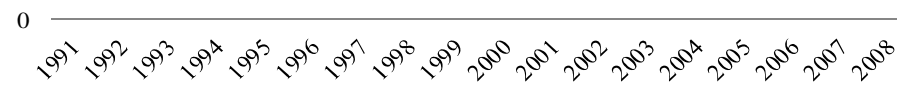

$\multimap$ Australia $\rightarrow$ China $\rightarrow$ Japan $\rightarrow$ Taiwan $\rightarrow$ UK $\rightarrow$ USA

Destination: Singapore

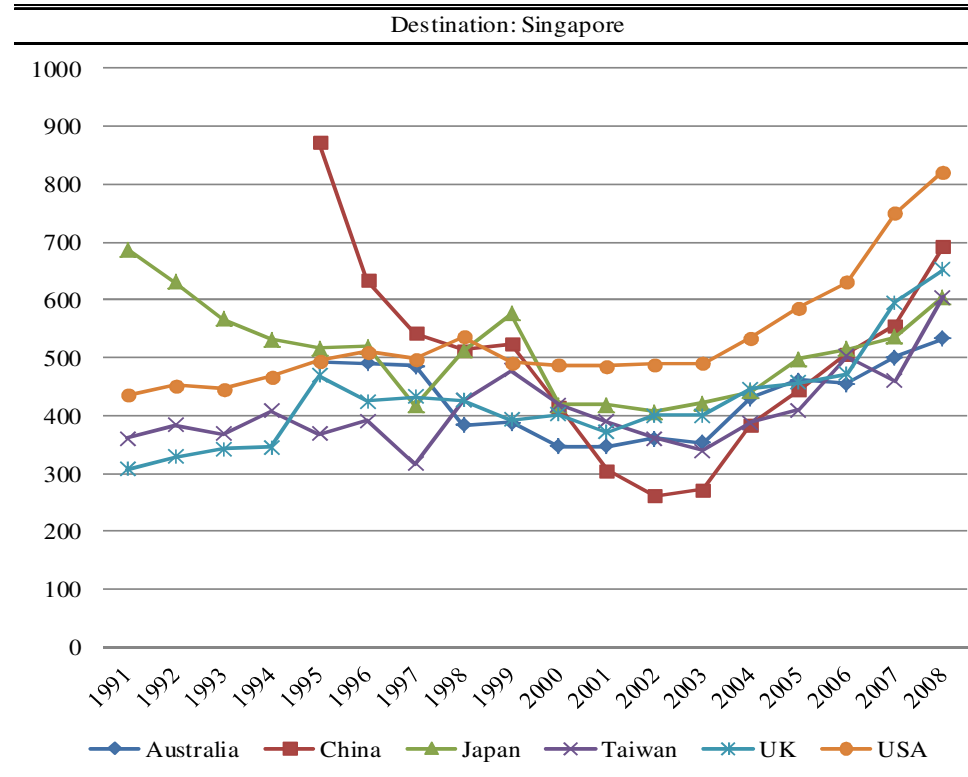

Note: a. Unit of expenditure per capita is US\$

b. Data for source market Australia and China start from 1995. 
For Hong Kong, it is obvious that the per capita spending has been stably increasing from $\$ 600$ to $\$ 800$ since 2000 , with growing spending by Chinese tourists and sluggish performance by Japanese tourists. For the competing destinations, they tend to have experienced much more volatilities. With regard to Singapore, it has seen a U-shape spending pattern by Chinese tourists over the sample period. Since 2003 a common trend of increasing spending has been observed among all six origins. For Macau, there has been a divergence between China and other five source markets since 2000 .

Price variables are relative (or effective) consumer price indexes adjusted by appropriate exchange rates and are used as proxies of tourism prices in Hong Kong relative to those in the source markets. Data on consumer price indexes (index value in $2000=100$ ) and exchange rate indexes (index value in $2000=100$ ) are collected from the International Financial Statistical Yearbook published by the International Monetary Fund. Figure 2 shows the evolution of relative consumer price indexes.

A general observation of Figure 2 is that relative prices in the four destinations for the six different origins have experienced varying degrees of fluctuations, and the trend keeps strengthening. Specifically, relative prices in Hong Kong have exhibited a downward trend for all origins since 2000. For most origins, the relative prices in 2008 were much lower than those in 2000. On the other hand, the relative prices in Korea seem to be robust, mostly above the level of 2000 . For Singapore, the prices fluctuate across different origins. 


\section{Figure 2. Relative Prices (Index) of Hong Kong and Its Competitors}

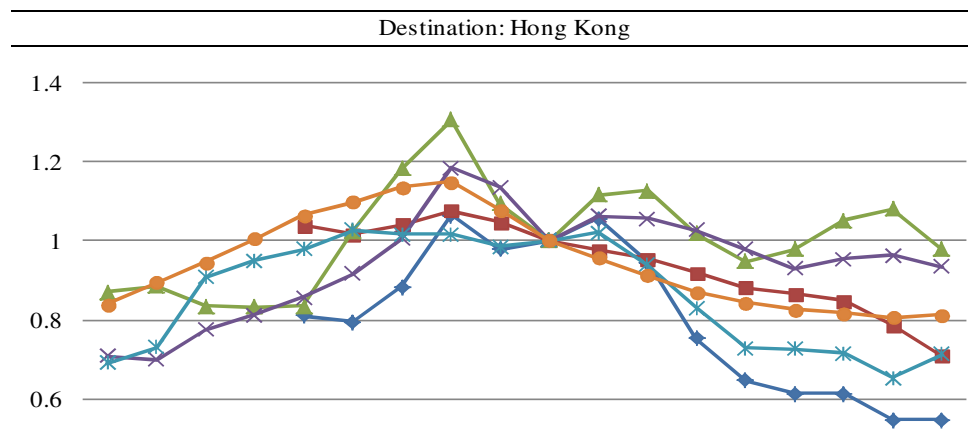

0.4

0.2

0

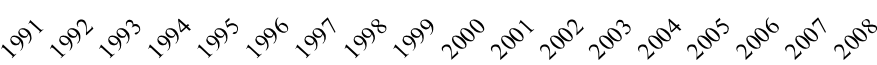

$\leadsto$ Australia $\rightarrow$ China $\rightarrow$ Japan $*$ Taiwan $\rightarrow$ UK $\rightarrow$ USA
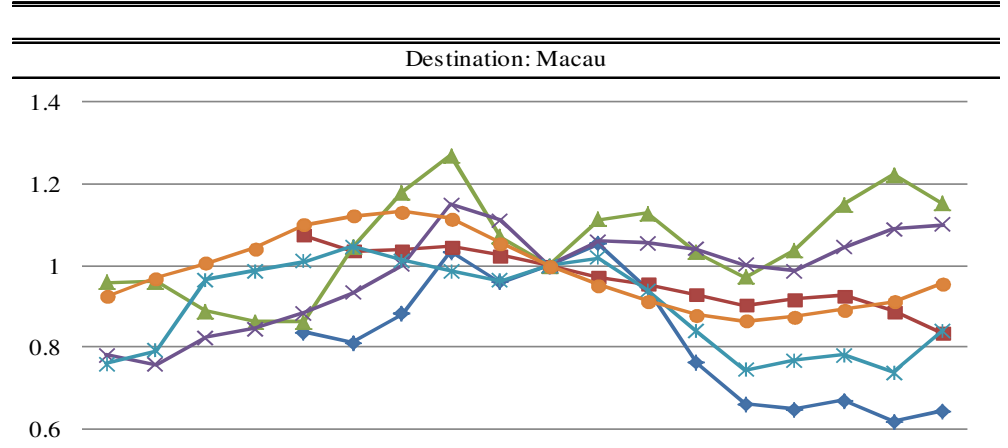

0.4

0.2

0

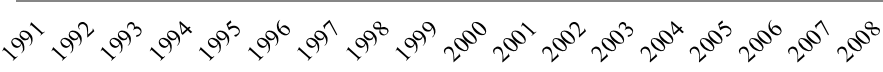

$\multimap$ Australia $\rightarrow$ China $\longrightarrow$ Japan $\rightarrow$ Taiwan $\rightarrow$ UK $\rightarrow$ USA

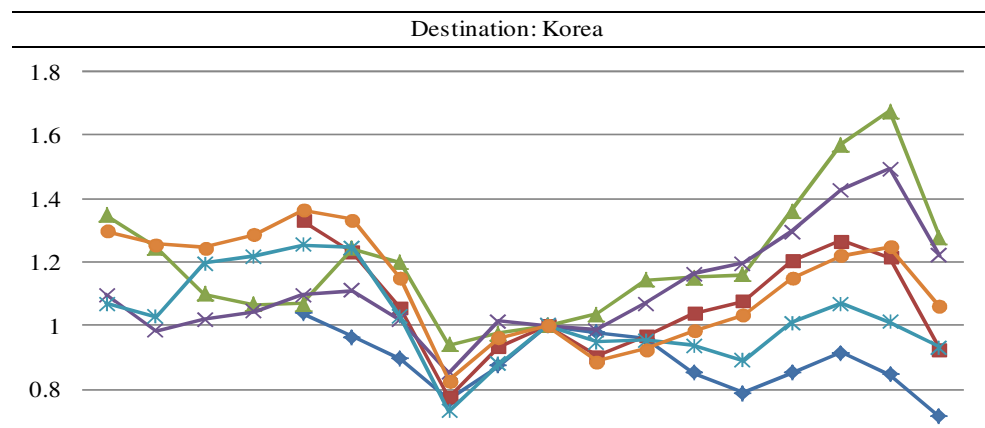

0.6

0.4

0.2

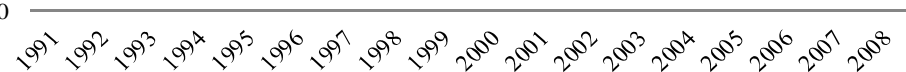

$\multimap$ Australia $\rightarrow$ China $\rightarrow$ Japan $\rightarrow$ Taiwan $\rightarrow$ UK $\multimap$ USA

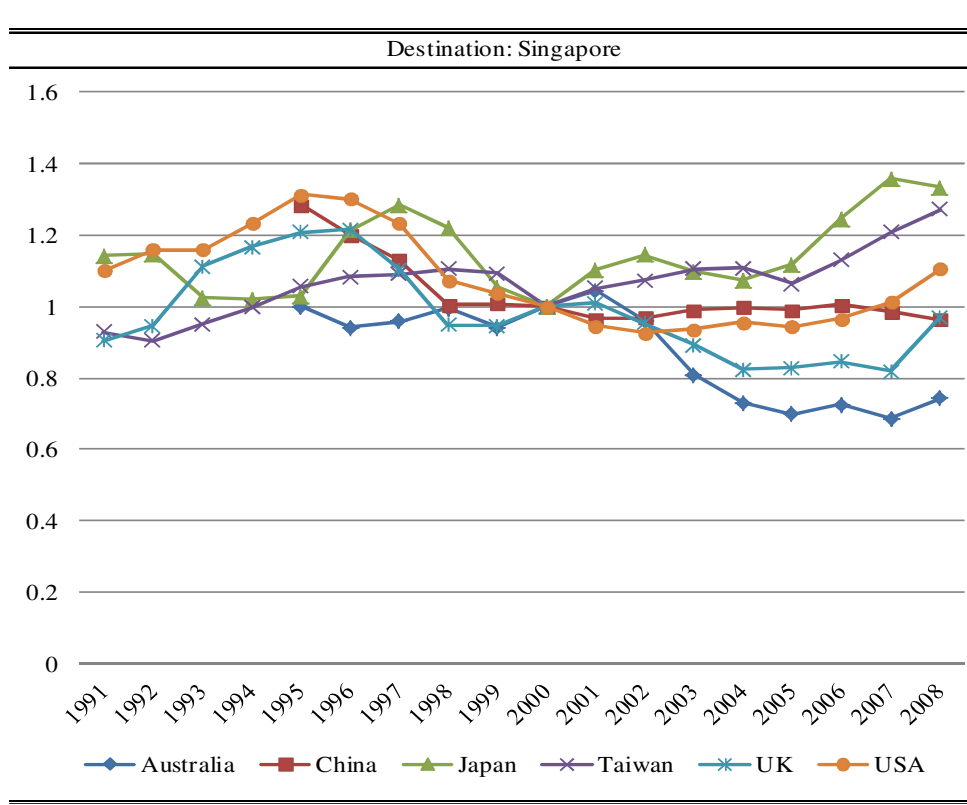

Note: a. Relative price is defined as $P_{j}=\left(C P I_{j} / E X_{j}\right) /\left(C P I_{\text {orig. }} / E X_{\text {orig. }}\right)$, where $j$ is the destination, $C P I$ and EX value in $2000=100$. b. Data for source market Australia and China start from 1995. 


\section{Empirical Results}

The estimates of restricted EC-AIDS models are presented in Table 1. All systems pass the three restriction tests for homogeneity and symmetry based on at least one of the two statistical tests. It is therefore appropriate to carry out the following analysis based on these estimated homogeneous and symmetric EC-LAIDS models. With respect to diagnostic tests, all models except one pass the autocorrelation test and the normality test at the 5\% significance level, the only exception being the case of the USA, where the normality test is passed at the $1 \%$ significance level.

With regard to demand elasticities, following the Engel-Granger two-stage approach to EC-LAIDS estimation, both long-run and short-run elasticities can be calculated. Long-run elasticities are derived from the static model in the first stage. As mentioned earlier and noted by Song and Witt (2000), lack of dynamics in the model specification and a relatively small sample size tend to affect the accuracy of the estimated elasticities. In comparison, the short-run elasticities are calculated based on the well-specified EC-LAIDS, and are therefore more accurate and reliable to draw useful policy implications. Therefore, the following analysis focuses on short-run elasticities only. This is also in line with recent practices in the EC-LAIDS studies (e.g., Cortés-Jiménez et al., 2009; Feleke \& Kilmer, 2007; Wu et al., 2011).

Tables 2-4 report the calculated short-run expenditure, own-price and cross-price elasticities derived from the estimated EC-LAIDS models presented in Table 1. The $t$ statistics of the elasticity values are calculated and statistically non-significant results are omitted from the tables. Overall, most short-run expenditure elasticities are significant and have the expected sign. In contrast, the effect of prices-both own price and cross-price elasticities-is not as significant as that of expenditure. Although this study only focuses on short-run elasticities, it is worth noting that, demand theory suggests the absolute values of short-run demand elasticities tend to be smaller than their long-run counterparts. 
Table 1. Estimates of the Homogeneity and Symmetry Restricted EC-LAIDS Models

\begin{tabular}{|c|c|c|c|}
\hline \multicolumn{4}{|l|}{$\frac{\text { Australia }}{(1997-2008)}$} \\
\hline & Hong Kong & Macau & Singapore \\
\hline intercept (c) & -0.001 & $0.001 *$ & 0.003 \\
\hline$\Delta \mathrm{w}_{\mathrm{t}-1}(\delta)$ & -0.058 & $0.606 * * *$ & $0.236^{*}$ \\
\hline$\Delta \ln \mathrm{P}_{\mathrm{hk}}\left(\gamma_{1}\right)$ & $-0.121 * * *$ & $0.089 * *$ & 0.022 \\
\hline$\Delta \ln \mathrm{P}_{\mathrm{ma}}\left(\gamma_{2}\right)$ & $0.089 * *$ & -0.037 & $-0.039 *$ \\
\hline$\Delta \ln P_{\mathrm{sg}}\left(\gamma_{3}\right)$ & 0.022 & $-0.039 *$ & -0.007 \\
\hline$\Delta \ln \mathrm{P}_{\mathrm{kr}}\left(\gamma_{4}\right)$ & 0.010 & $-0.013 * *$ & 0.023 \\
\hline$\Delta \ln \left(\mathrm{x} / \mathrm{P}^{*}\right)(\mathrm{b})$ & 0.021 & -0.007 & -0.023 \\
\hline $\operatorname{ECT}(\lambda)$ & $-1.813^{* * *}$ & $-2.150 * * *$ & $-1.602 * * *$ \\
\hline \multicolumn{4}{|l|}{ D97 $\left(\varphi_{1}\right)$} \\
\hline \multicolumn{4}{|l|}{$\operatorname{DSARS}\left(\varphi_{2}\right)$} \\
\hline $\mathrm{R}^{2}$ & 0.898 & 0.952 & 0.847 \\
\hline \multicolumn{4}{|c|}{ Diagnostic Tests (p-value) } \\
\hline Autocorrelation & 0.722 & & \\
\hline Normality & 0.528 & & \\
\hline \multicolumn{4}{|l|}{$\underline{\text { Restriction Tests }}$} \\
\hline & $\mathrm{T}_{1}$ & $\mathrm{~T}_{2}$ & \\
\hline Homogeneity & $0.598 * * *$ & $1.794 * * *$ & \\
\hline Symmetry & $1.672 * * *$ & $5.017 * * *$ & \\
\hline $\mathbf{H}+\mathbf{S}$ & $0.993 * * *$ & $5.956 * * *$ & \\
\hline
\end{tabular}

\begin{tabular}{|c|c|c|c|}
\hline \multicolumn{4}{|l|}{$\begin{array}{l}\text { China } \\
(1997-2008)\end{array}$} \\
\hline & Hong Kong & Macau & Singapore \\
\hline intercept (c) & -0.006 & $0.012 * * *$ & -0.001 \\
\hline \multicolumn{4}{|l|}{$\Delta \mathrm{w}_{\mathrm{t}-1}(\delta)$} \\
\hline$\Delta \ln \mathrm{P}_{\mathrm{hk}}\left(\gamma_{1}\right)$ & $-0.292 * *$ & $0.337 * *$ & 0.032 \\
\hline$\Delta \ln \mathrm{P}_{\mathrm{ma}}\left(\gamma_{2}\right)$ & $0.337 * *$ & -0.253 & -0.081 \\
\hline$\Delta \ln \mathrm{P}_{\mathrm{sg}}\left(\gamma_{3}\right)$ & 0.032 & -0.081 & 0.106 \\
\hline$\Delta \ln \mathrm{P}_{\mathrm{kr}}\left(\gamma_{4}\right)$ & -0.077 & -0.003 & -0.056 \\
\hline$\Delta \ln \left(\mathrm{x} / \mathrm{P}^{*}\right)(\mathrm{b})$ & $-0.199 * * *$ & -0.048 & -0.108 \\
\hline $\operatorname{ECT}(\lambda)$ & $-0.481 * * *$ & $-1.183 * * *$ & -0.130 \\
\hline \multicolumn{4}{|l|}{ D97 $\left(\varphi_{1}\right)$} \\
\hline $\operatorname{DSARS}\left(\varphi_{2}\right)$ & $0.045^{* *}$ & -0.003 & 0.001 \\
\hline $\mathrm{R}^{2}$ & 0.791 & 0.699 & 0.135 \\
\hline \multicolumn{4}{|c|}{ Diagnostic Tests (p-value) } \\
\hline Autocorrelation & 0.552 & & \\
\hline Normality & 0.975 & & \\
\hline \multicolumn{4}{|l|}{$\underline{\text { Restriction Tests }}$} \\
\hline & $\mathrm{T}_{1}$ & $\mathrm{~T}_{2}$ & \\
\hline Homogeneity & $2.121 * * *$ & $6.362 * *$ & \\
\hline Symmetry & $4.625^{*}$ & 13.874 & \\
\hline $\mathbf{H}+\mathbf{S}$ & $4.285^{*}$ & 25.707 & \\
\hline
\end{tabular}

\begin{tabular}{|c|c|c|c|}
\hline \multicolumn{4}{|l|}{$\frac{\text { Japan }}{(1993-2008)}$} \\
\hline & Hong Kong & Macau & Singapore \\
\hline intercept (c) & -0.002 & 0.000 & -0.002 \\
\hline \multicolumn{4}{|l|}{$\Delta \mathrm{w}_{\mathrm{t}-1}(\delta)$} \\
\hline$\Delta \ln P_{h k}\left(\gamma_{1}\right)$ & 0.051 & 0.050 & -0.129 \\
\hline$\Delta \ln P_{\mathrm{ma}}\left(\gamma_{2}\right)$ & 0.050 & -0.081 & 0.052 \\
\hline$\Delta \ln P_{\mathrm{sg}}\left(\gamma_{3}\right)$ & -0.129 & 0.052 & 0.042 \\
\hline$\Delta \ln \mathrm{P}_{\mathrm{kr}}\left(\gamma_{4}\right)$ & 0.028 & -0.020 & 0.035 \\
\hline$\Delta \ln \left(\mathrm{x} / \mathrm{P}^{*}\right)(\mathrm{b})$ & -0.015 & $-0.022 *$ & 0.014 \\
\hline $\operatorname{ECT}(\lambda)$ & -0.457 & $-1.068 * * *$ & $-0.990 * * *$ \\
\hline D97 $\left(\varphi_{1}\right)$ & -0.006 & -0.009 & $0.039 *$ \\
\hline \multicolumn{4}{|l|}{$\operatorname{DSARS}\left(\varphi_{2}\right)$} \\
\hline $\mathrm{R}^{2}$ & 0.166 & 0.626 & 0.485 \\
\hline \multicolumn{4}{|c|}{ Diagnostic Tests (p-value) } \\
\hline Autocorrelation & 0.263 & & \\
\hline Normality & 0.921 & & \\
\hline \multicolumn{4}{|l|}{$\underline{\text { Restriction Tests }}$} \\
\hline & $\mathrm{T}_{1}$ & $\mathrm{~T}_{2}$ & \\
\hline Homogeneity & $1.435 * * *$ & $4.304 * * *$ & \\
\hline Symmetry & $2.505^{* *}$ & $7.515^{* *}$ & \\
\hline $\mathbf{H}+\mathbf{S}$ & $2.597 *$ & $15.580 *$ & \\
\hline
\end{tabular}




\begin{tabular}{|c|c|c|c|}
\hline \multicolumn{4}{|l|}{$\frac{\text { Taiwan }}{(1993-2008)}$} \\
\hline & Hong Kong & Macau & Singapore \\
\hline \multicolumn{4}{|l|}{ intercept (c) } \\
\hline$\Delta \mathrm{w}_{\mathrm{t}-1}(\delta)$ & 0.319 & $0.948 * * *$ & 0.207 \\
\hline$\Delta \ln \mathrm{P}_{\mathrm{hk}}\left(\gamma_{1}\right)$ & -0.011 & 0.022 & -0.010 \\
\hline$\Delta \ln \mathrm{P}_{\mathrm{ma}}\left(\gamma_{2}\right)$ & 0.022 & -0.104 & 0.047 \\
\hline$\Delta \ln \mathrm{P}_{\mathrm{sg}}\left(\gamma_{3}\right)$ & -0.010 & 0.047 & 0.043 \\
\hline$\Delta \ln \mathrm{P}_{\mathrm{kr}}\left(\gamma_{4}\right)$ & -0.001 & $0.035^{*}$ & -0.081 \\
\hline$\Delta \ln \left(\mathrm{x} / \mathrm{P}^{*}\right)(\mathrm{b})$ & $-0.136^{* *}$ & $-0.063 * * *$ & $-0.111^{* *}$ \\
\hline $\operatorname{ECT}(\lambda)$ & $-0.580 * *$ & $-2.116 * * *$ & $-1.248 * * *$ \\
\hline \multicolumn{4}{|l|}{$\operatorname{D} 97\left(\varphi_{1}\right)$} \\
\hline \multicolumn{4}{|l|}{$\operatorname{DSARS}\left(\varphi_{2}\right)$} \\
\hline $\mathrm{R}^{2}$ & 0.441 & 0.676 & 0.727 \\
\hline \multicolumn{4}{|c|}{ Diagnostic Tests (p-value) } \\
\hline Autocorrelation & 0.521 & & \\
\hline Normality & 0.807 & & \\
\hline \multicolumn{4}{|l|}{$\underline{\text { Restriction Tests }}$} \\
\hline & $\mathrm{T}_{1}$ & $\mathrm{~T}_{2}$ & \\
\hline Homogeneity & $1.885^{* * *}$ & $5.655 * * *$ & \\
\hline Symmetry & $2.140 * * *$ & $6.419^{* *}$ & \\
\hline $\mathbf{H}+\mathbf{S}$ & $2.288 * *$ & $13.730^{*}$ & \\
\hline
\end{tabular}

\begin{tabular}{|c|c|c|c|}
\hline \multicolumn{4}{|l|}{$\begin{array}{l}\underline{\mathrm{UK}} \\
(1993-2008)\end{array}$} \\
\hline & Hong Kong & Macau & Singapore \\
\hline intercept (c) & -0.005 & 0.001 & 0.003 \\
\hline \multicolumn{4}{|l|}{$\Delta \mathrm{w}_{\mathrm{t}-1}(\delta)$} \\
\hline$\Delta \ln \mathrm{P}_{\mathrm{hk}}\left(\gamma_{1}\right)$ & -0.017 & 0.143 & -0.042 \\
\hline$\Delta \ln \mathrm{P}_{\mathrm{ma}}\left(\gamma_{2}\right)$ & 0.143 & -0.113 & 0.015 \\
\hline$\Delta \ln \mathrm{P}_{\mathrm{sg}}\left(\gamma_{3}\right)$ & -0.042 & 0.015 & $0.122^{*}$ \\
\hline$\Delta \ln \mathrm{P}_{\mathrm{kr}}\left(\gamma_{4}\right)$ & -0.084 & $-0.045^{*}$ & $-0.095 * * *$ \\
\hline$\Delta \ln \left(\mathrm{x} / \mathrm{P}^{*}\right)(\mathrm{b})$ & $-0.123^{*}$ & -0.013 & -0.010 \\
\hline $\operatorname{ECT}(\lambda)$ & $-0.741^{*}$ & -0.467 & -0.107 \\
\hline$\Delta \mathrm{D} 97\left(\varphi_{1}\right)$ & 0.015 & $-0.031 * * *$ & $-0.031 * *$ \\
\hline \multicolumn{4}{|l|}{$\Delta \operatorname{DSARS}\left(\varphi_{2}\right)$} \\
\hline $\mathrm{R}^{2}$ & 0.415 & 0.771 & 0.583 \\
\hline \multicolumn{4}{|c|}{ Diagnostic Tests (p-value) } \\
\hline Autocorrelation & 0.304 & & \\
\hline Normality & 0.136 & & \\
\hline \multicolumn{4}{|l|}{ Restriction Tests } \\
\hline & $\mathrm{T}_{1}$ & $\mathrm{~T}_{2}$ & \\
\hline Homogeneity & $3.669^{*}$ & $11.008^{*}$ & \\
\hline Symmetry & $0.122 * * *$ & $0.365^{* * *}$ & \\
\hline $\mathbf{H}+\mathbf{S}$ & $1.875^{* * *}$ & $11.248^{* *}$ & \\
\hline
\end{tabular}

\begin{tabular}{|c|c|c|c|}
\hline \multicolumn{4}{|l|}{$\frac{\underline{\text { USA }}}{(1993-2008)}$} \\
\hline & Hong Kong & Macau & Singapore \\
\hline \multicolumn{4}{|l|}{ intercept (c) } \\
\hline$\Delta \mathrm{w}_{\mathrm{t}-1}(\delta)$ & -0.078 & -0.152 & -0.095 \\
\hline$\Delta \ln \mathrm{P}_{\mathrm{hk}}\left(\gamma_{1}\right)$ & -0.057 & 0.157 & -0.036 \\
\hline$\Delta \ln \mathrm{P}_{\mathrm{ma}}\left(\gamma_{2}\right)$ & 0.157 & -0.165 & -0.012 \\
\hline$\Delta \ln \mathrm{P}_{\mathrm{sg}}\left(\gamma_{3}\right)$ & -0.036 & -0.012 & $0.182 * * *$ \\
\hline$\Delta \ln \mathrm{P}_{\mathrm{kr}}\left(\gamma_{4}\right)$ & -0.064 & 0.021 & $-0.134 * * *$ \\
\hline$\Delta \ln \left(\mathrm{x} / \mathrm{P}^{*}\right)(\mathrm{b})$ & $-0.200 * * *$ & -0.026 & $-0.172 * * *$ \\
\hline $\operatorname{ECT}(\lambda)$ & $-1.002 * *$ & $-0.678^{*}$ & 0.346 \\
\hline \multicolumn{4}{|l|}{$\Delta \mathrm{D} 97\left(\varphi_{1}\right)$} \\
\hline \multicolumn{4}{|l|}{$\Delta \operatorname{DSARS}\left(\varphi_{2}\right)$} \\
\hline $\mathrm{R}^{2}$ & 0.719 & 0.605 & 0.750 \\
\hline \multicolumn{4}{|c|}{ Diagnostic Tests (p-value) } \\
\hline Autocorrelation & 0.716 & & \\
\hline Normality & 0.036 & & \\
\hline \multicolumn{4}{|l|}{ Restriction Tests } \\
\hline & $\mathrm{T}_{1}$ & $\mathrm{~T}_{2}$ & \\
\hline Homogeneity & $0.038^{* * *}$ & $0.113 * * *$ & \\
\hline Symmetry & $2.930 * *$ & $8.790 *$ & \\
\hline $\mathbf{H}+\mathbf{S}$ & $1.474 * * *$ & $8.841 * * *$ & \\
\hline
\end{tabular}

Note: a. For each demand system, parameters in the equation for South Korea are omitted but can be calculated according to adding-up restrictions. b. *, ** and *** on the parameters denote significance at the 10\%, 5\% and $1 \%$ levels, respectively.

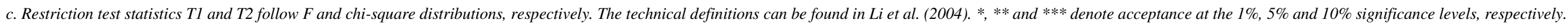


Table 2. Short-Run Expenditure Elasticities by Source Market

\begin{tabular}{lllllll}
\hline \hline & Australia & China & Japan & Taiwan & UK & USA \\
\hline Hong Kong & $1.083^{* * *}$ & & $0.945^{* * *}$ & $0.558^{* * *}$ & $0.530^{* * *}$ & $0.220^{*}$ \\
Macau & $0.872^{* * *}$ & $0.587^{* *}$ & $0.598^{* * *}$ & & & \\
Singapore & $0.859 * * *$ & & $1.072^{* * *}$ & & $0.941^{* * *}$ & \\
South Korea & $1.017 * * *$ & $1.739 * * *$ & $1.048^{* * *}$ & $1.674 * * *$ & $1.276^{* * *}$ & $1.763^{* * *}$ \\
\hline \hline
\end{tabular}

Expenditure elasticities. Among the four destinations concerned, Macau is viewed as a "necessity good" for which the elasticities are always below unity. South Korea is perceived as a "luxury good" with expenditure elasticities ranging from 1.017 to 1.763 , significant in all the markets under study. The results for Hong Kong and Singapore are mixed. In particular, three markets (Taiwan, the UK and the USA) regard Hong Kong as a "necessity good", but this perception is not clearly held in the other markets. Hong Kong faces the most divergent market perceptions across the source markets under study. Singapore provides a contrast, in that although the elasticity values are either above one or lower than one, they are all close to unity (from 0.859 to 1.072 ).

Some comparisons can be made between Macau and South Korea, both of which are dominated by leisure tourists. According to the Macau Government Tourist Office (2011) and the Korea Tourism Organization (2011a), over two-thirds of the visitors to these two destinations are there for a vacation purpose. However, in terms of diversification, Macau, with overwhelmingly an urban setting led by the gaming and entertainment sector, is deemed to be inferior to South Korea. Once a higher budget is available, tourists are much more likely to explore the abundant landscapes and attractions of South Korea. South Korea therefore holds some competitive advantages over the other three destinations, particularly in times of economic expansion. In addition, the extent to which Macau is viewed as a necessity good can be explained by the addiction of regular gaming visitors.

There are close similarities between Hong Kong and Singapore. The status of both cities as global commercial centers means Hong Kong and Singapore receive relatively high proportions of business travelers. For example, $19 \%$ and $28 \%$ of total visitors in Hong Kong and Singapore, respectively, traveled for business and meetings purposes in 2008, in contrast to $37 \%$ and $39 \%$ of total visitors who were holiday makers in these two destinations (Hong Kong Tourism Board, 2011; Department of Statistics Singapore, 2011). With their well-diversified tourist segments, Hong Kong and Singapore saw relatively robust demand and suffered only mildly from the decline in tourist expenditure during the recent economic downturn in comparison with South Korea.

Table 3. Short-Run Own-Price Elasticities by Source Market

\begin{tabular}{|c|c|c|c|c|c|c|}
\hline & Australia & China & Japan & Taiwan & UK & USA \\
\hline Hong Kong & $-1.209 * * *$ & $-1.998 * * *$ & & $-0.728 * * *$ & $-0.802 * *$ & $-0.968 * *$ \\
\hline Macau & $-1.598 * *$ & $-3.041 *$ & & $-2.552 *$ & & \\
\hline Singapore & $-0.876 * * *$ & & & & & \\
\hline South Korea & $-0.518 * * *$ & & $-0.618 * * *$ & $-0.435 * * *$ & & $-0.139 *$ \\
\hline
\end{tabular}


Own price elasticities. As Table 3 suggests, demand for tourism in Macau and Hong Kong is generally more price-sensitive than that in Singapore and South Korea. Macau tourism is most influenced by its prices among the four competitors, with elasticities as low as -3.0. In contrast, price increases barely affect tourist expenditure in Singapore (for which the elasticity values are not statistically different from zero in five out of six cases). The low level of price sensitivity might be an indication that Singapore enjoys a significant competitive advantage. In comparison, Macau is in the least advantageous position, while Hong Kong and South Korea occupy the middle positions among the four competitors. As far as individual source markets are concerned, mainland Chinese, Australian and Taiwanese tourists seem to be more price-sensitive than Japanese, British and American tourists. The level of price sensitivity is positively related to the degree of competition in the market (Anderson, 1996). When the competition is fierce, consumers find it relatively easy to switch across competitors driven by lower prices, and their demand may therefore appear more price-elastic. Particular attention should be paid to mainland China. This market is the most price-sensitive of those examined, particularly as far as the demand for Hong Kong and Macau tourism is concerned (-1.998 and -3.041, respectively). Given the predominant market shares of this market in both Hong Kong and Macau $(57.1 \%$ and $50.6 \%$ of total arrivals, respectively, in 2008), these destinations need to monitor their pricing strategies carefully to retain their market shares and compete for more visitors from mainland China. When the shadow of inflation is cast on both destinations, the loss of tourism receipts from the mainland Chinese market will bring their overall performance into question.

While competitiveness is revealed in relative terms by elasticities, it can also be viewed from another perspective. As ranked by The Travel \& Tourism Competitiveness Report 2011 (Blanke $\&$ Chiesa, 2011), Singapore is the most price competitive $\left(29^{\text {th }}\right.$ out of 135) of the four destinations, compared to Hong Kong $\left(71^{\text {st }}\right)$ and South Korea $\left(96^{\text {th }}\right)$ (regrettably, Macau is not ranked in this report). Singapore therefore enjoys a somewhat advantageous position with an attractive price level as tourists to Singapore tend to be price insensitive. In line with its "luxury" status, South Korea is seen as an expensive destination, but price cuts may only boost the inflow of visitors to a limited extent. Hong Kong has some degree of price competitiveness, but demand is subject to drastic price variations.

Table 4. Short-Run Cross-Price Elasticities by Source Market

\begin{tabular}{|c|c|c|c|c|c|c|}
\hline & Australia & China & Japan & Taiwan & UK & USA \\
\hline Hong Kong-Macau & $0.399 * * *$ & $1.543 * *$ & & & & \\
\hline Macau-Hong Kong & $1.842 * * *$ & $3.107 * *$ & & & & \\
\hline Hong Kong-Singapore & $0.250 * *$ & & & & & \\
\hline Singapore-Hong Kong & $0.396 * *$ & & & & & \\
\hline $\begin{array}{l}\text { Hong Kong-South } \\
\text { Korea }\end{array}$ & $0.560 * * *$ & & $0.577 * *$ & $0.456 * * *$ & & $0.271^{*}$ \\
\hline $\begin{array}{l}\text { South Korea-Hong } \\
\text { Kong }\end{array}$ & $0.279 * * *$ & & $0.336^{* *}$ & $0.305 * * *$ & & $0.133^{*}$ \\
\hline
\end{tabular}

Cross-price elasticities. The substitution effect indicated by the cross-price elasticities of demand calculated here is useful in analyzing competition among Hong Kong and its major rivals. The elasticities presented in the first, third and fifth rows of Table 4 reflect how the demand for tourism in Hong Kong reacts to competitors' price changes; the elasticities in the second, fourth, and sixth rows of Table 4 indicate how the demand for other destinations reacts to Hong Kong's price variations. Comparing each pair of cross-price elasticities reveals Hong Kong's competitiveness. Overall, there appears to be no price competition between Singapore and Hong Kong, while South Korea has the most notable substitution effects over Hong Kong (in 
four out of the six markets under study). Competition from Macau is evident in the Australian and mainland Chinese markets, but not in the others. Again, the critical Chinese market is a battlefield to fight for. As indicated by the unusually high cross elasticities (1.543 and 3.107), tourists from mainland China are easily lured by alternative destinations. Although the two destinations-Hong Kong and Macau - are neighbors and can be visited on the same trip, the separate visa application procedures to some extent require mainland Chinese visitors to make a choice between the two before embarking on their journey. The concern arises with South Korea, a destination with which Hong Kong has to compete for tourists in more markets such as Japan and Taiwan. However, the cross-price elasticities for Hong Kong are larger than those for South Korea. For example, in the case of Japan (see Table 4), the cross-price elasticity for Hong Kong vs. South Korea is 0.577 , and that for South Korea vs. Hong Kong is 0.336. The former measures the effect of South Korea prices on the demand for Hong Kong, while the latter measures that of Hong Kong prices on the demand for South Korea. Once prices go down by the same degree in both destinations, more tourists - especially those from Australia, Japan, Taiwan and the USAwould abandon their plans to travel to Hong Kong in favor of South Korea.

\section{Discussion on Policy Implications}

Pricing strategy is a powerful tool in enhancing a destination's competitiveness. In his empirical research on customer satisfaction and price tolerance, Anderson (1996) suggested that as competition in an industry that provides simpler products increases, i.e., the availability of alternative products increases, the maximum price increase that customers are willing to tolerate would fall because they can readily switch between choices. To attract and retain customers, firms have to increase customer satisfaction in view of the lower level of price tolerance. Furthermore, Anderson (1996) observed a positive association between year-to-year changes in the levels of customer satisfaction and price tolerance. From the firm perspective, increasing customer satisfaction is, therefore, likely to reduce the price elasticity of demand.

In the context of tourism, if competition among alternative destinations is keen, it is wise for a destination to take necessary measures to increase tourists' satisfaction level. This should be achieved through appropriate quality assurance programs instead of price cuts, which may result in a price war among competing destinations from which no destination can ultimately benefit. The tourism sector should consider the financial benefits of improving satisfaction as a consequence of tourists' increased willingness to tolerate price increases. Meanwhile, the level of satisfaction can also affect the formation of tourists' habits (i.e., destination loyalty). Many tourists, if satisfied with the destination, are known to develop a habit of making repeated visits, thus making markets relatively insulated from price and expenditure-related fluctuations in tourist arrivals (Bakkal, 1991; Divisekera, 2003). In a study of demand for outbound tourism by British residents, Lyssiotou (2000) found that habit persistence could contribute to up to $36 \%$ of current tourism expenditure. This result shows that tourists' decisions can be made largely based on the experience gained from past visits. Thus, destinations can increase their share of the market in a specific origin country by creating a habituated tourist clientele, a situation to which a high level of satisfaction can contribute.

Although prices do not play a dominant role in every market examined in the present study, they do matter to some key origin markets on which the destination could be largely reliant. In the case of Hong Kong, all except one source markets show significant own-price elasticities that are approximately equal to or above unity (in absolute value), the only exception being Japan. In comparison with Singapore and South Korea for which tourism demand is less price-elastic, Hong Kong has less of a competitive advantage. Thus, tourism related businesses in Hong Kong need to monitor price trends closely and manage their pricing strategies carefully. In addition, the Hong Kong government should ensure that inflation is maintained at a stable and reasonably low level and take policy measures to control the price increases if necessary. 
As revealed by the above cross-price elasticity analysis, Hong Kong and Macau are strong competitors, particularly in the Australian and mainland Chinese markets. Although Hong Kong appears to have a competitive advantage over Macau, careful pricing strategies and policy measures should be considered because the Australian and mainland Chinese markets show a high likelihood of switching between Hong Kong and Macau due to price changes. Therefore, efforts should be made to develop a better understanding of the nature of these markets and to raise their price tolerance. Hong Kong should efficiently maintain its position by improving tourist satisfaction without sparking a price war. Hong Kong's smaller own price elasticities show that price cuts are not likely to yield the same economic return as that gained in Macau. Instead, Hong Kong will benefit from more stable demand due to a decrease in price sensitivity when tourists find they are more satisfied.

The significant cross-price elasticities found in four out of the six markets show that South Korea competes with Hong Kong in a wider range of markets, although the degree of the substitution effect is not as high as that for Macau. As discussed earlier, South Korea has a variety of attractions to promote such as medical tourism, eco-tourism and cruise tours (Korea Tourism Organization, 2011b), all of which are catered for the needs of an increasingly sophisticated customer base. As pointed out by Divisekera (2003, p. 47), for destinations facing relatively inelastic demand and searching for a response, "...differentiating tourism services and marketing are necessary if these countries are to capture a substantial proportion of rising income from the tourist." Hong Kong must therefore capture the opportunities to diversify its services. For instance, Hong Kong's private hospital system is renowned for its high standards, and the fact it has gained international accreditation is conducive to the development of medical tourism.

With regard to Singapore and Hong Kong, the generally non-significant cross-price elasticities suggest that price is not a key concern in terms of competition between the two cities. The "Lion City" enjoys a relatively consistent level of demand irrespective of tourists' income changes. In addition, tourists are not sensitive to price variations in Singapore, potentially suggesting Singapore has a competitive edge over Hong Kong. As indicated by the Travel \& Tourism Competitiveness Report 2011, competition between Singapore and Hong Kong takes place in other aspects than price. As ranked by the competitiveness report, both cities are highly rated for such key areas as policy environment, safety and security, and transport infrastructure. In addition, Singapore leads the rankings for overall prioritization of the travel and tourism industry, the quality of human resources and environmental sustainability, while Hong Kong is superior for its quality of health and hygiene. The key issue is to transform the excellence displayed in these key aspects into economic returns. In this regard, it would be beneficial for Hong Kong to initiate mutual learning with Singapore as argued by Wong, Bauer, and Wong (2008). A particular focus should be placed on developing integrative strategies to engage external resources such as education and human resources in order to facilitate the development of the tourism sector in a cohesive manner. In addition, environmental regulation and policy is another area in which the Hong Kong government can learn from its Singapore counterpart to enhance its environmental sustainability.

\section{Conclusion}

This study analyzes the competitiveness of destinations using both economic theory and an advanced econometric method. Rigorous demand elasticity analysis based on the EC-LAIDS model provides useful insights into Hong Kong's competitiveness as an international tourist destination in comparison with its neighbouring competitors of Macau, Singapore and South Korea. This study adds a new perspective to the destination competitiveness literature and contributes to the literature by employing a dynamic AIDS model to analyze the different competitive positions occupied by a destination in a range of source markets. The study 
recognizes that differences between markets should be taken into consideration in evaluating a destination's competitiveness. Overall, this study finds that Hong Kong has a competitive advantage over Macau, particularly in the Australian and mainland Chinese markets. However, Singapore and South Korea appear to be in a better competitive position than Hong Kong. To improve the competitiveness of Hong Kong as an international destination, the tourism industry should pay close attention to its pricing strategy and the government needs to monitor and control inflation carefully. In addition, Hong Kong should continue to promote its "quality tourism services" scheme and improve tourist satisfaction.

The unavailability of data and the small sample size restrict the scope and depth of the current study. To draw more insights and reach more robust findings, future studies of Hong Kong's competitiveness as a destination should focus on the city level instead of the country level once the required data are available. In addition, to develop a more complete demand system for each source market, origin-specific competitors of Hong Kong should be considered in addition to the three competitors considered in this study once data availability and the sample size allow. Thus a more comprehensive and larger-scale competitiveness analysis could be conducted and more useful policy implications could be drawn. Another direction of future research is to consider alternative proxies for tourism prices and examine their effects on the empirical results.

\section{Acknowledgements}

The authors would like to acknowledge the financial support of The Hong Kong Polytechnic University (Grant No. GU-332).

\section{References}

Anderson, E. (1996). Customer Satisfaction and Price Tolerance. Marketing Letters, 7(3): 265274.

Anderson, G., \& Blundell, R. (1983). Testing Restrictions in a Flexible Dynamic Demand System : An Application to Consumers' Expenditure in Canada. Review of Economics Studies, 50(3): 397-410.

Bakkal, I. (1991). Characteristics of West German Demand for International Tourism in the Northern Mediterranean Region. Applied Economics, 23(2): 295-304.

Blanke, J., \& Chiesa, T. (Eds.). (2011). The Travel \& Tourism Competitiveness Report 2011: Beyond the Downturn. World Economic Forum, Geneva, Switzerland 2011.

Bueno, A. (1999). Competitiveness in the Tourist Industry and the Role of the Spanish Public Administration. Turizam, Special Issue on Competitiveness in Tourism and Hospitality, 47(4): 316-331.

Cizmar, S. \& Seric, M. (1999). Market Effectiveness and Internal Efficiency of Croatian Hotel Industry. Turizam, Special Issue on Competitiveness in Tourism and Hospitality 47(4): 300-315.

Cortés-Jiménez, I., Durbarry, R., \& Pulina, M. (2009). Estimation of Outbound Italian Tourism Demand: A Monthly Dynamic EC-LAIDS Model. Tourism Economics, 15(3): 547-565.

Court, R. H. (1968). An Application of Demand Theory to Projecting New Zealand Retail Consumption. The Economic Review, 3: 401-411.

Croes, R. (2011). Measuring and Explaining Competitiveness in the Context of Small Island Destinations. Journal of Travel Research, 50(4), 431-442.

Crouch, G., \& Ritchie, J. B. R. (1994). Destination Competitiveness: Exploring Foundations for a Long-Term Research Program. Proceedings of the Administrative Sciences Association of Canada Annual Conference, Halifax, Nova Scotia, June 25-28, 1994, 79-88.

Deaton, A. (1974). The Analysis of Consumer Demand in the United Kingdom, 1900-1970. Econometrica, 42(2): 341-61. 
Deaton, A. S., \& Muellbauer, J. (1980). An Almost Ideal Demand System. American Economic Review, 70(3): 312-326.

De Mello, M., Pack, A., \& Sinclair, M. T. (2002). A System of Equations Model of UK Tourism Demand in Neighbouring Countries. Applied Economics, 34(4): 509-521.

Department of Statistics Singapore. (2011). Annual Tourism Statistics. Retrieved June 7, 2011, from http://www.singstat.gov.sg/stats/themes/economy/tourism.html

d'Harteserre, A. (2000). Lessons in Managerial Destination Competitiveness in the Case of Foxwoods Casino Resort. Tourism Management, 21(1): 23-32.

Divisekera, S. (2003). A Model of Demand for International Tourism. Annals of Tourism Research, 30(1): 31-49.

Duffy, M. (2003). Advertising and Food, Drink and Tobacco Consumption in the United Kingdom: A Dynamic Demand System. Agricultural Economics, 28(1): 51-70.

Dwyer, L., Forsyth, P., \& Rao, P. (2000). The Price Competitiveness of Travel and Tourism: A Comparison of 19 Destinations. Tourism Management, 21(1): 9-22.

Edgerton, D. L., Assarsson, B., Hummelmose, A., Laurila, I. P., Rickertsen, K., \& Vale, P. H. (1996). The Econometrics of Demand Systems with Applications to Food Demand in the Nordic Countries. London: Kluwer Academic Publishers.

Elliott, G., Rothenberg, T., \& Stock, J. H. (1996). Efficient Tests for an Autoregressive Unit Root. Econometrica, 64(4), 813-836.

Enright, M., \& Newton, J. (2004). Tourism Destination Competitiveness: a Quantitative Approach. Tourism Management, 25(6): 777-788.

European Commission. (1994). Enhancing European Competitiveness, 2nd Report to the President of the Commission, Competitiveness Advisory group, European Commission, Luxembourg: OPEC.

Feleke, S. T., \& Kilmer, R. L. (2007). Analysis of the Demand for Imported Meat in Switzerland Using a Dynamic Specification: Implications for the European Union. Agribusiness, 23(4): 497-510.

Go, F., \& Govers, R. (2000). Integrated Quality Management for Tourist Destinations: A European Perspective on Achieving Competitiveness. Tourism Management, 21(1): 79-88.

Han, Z., Durbarry, R., \& Sinclair, M. T. (2006). Modelling US Tourism Demand for European Destinations. Tourism Management, 27(1): 1-10.

Hassan, S. (2000). Determinants of Market Competitiveness in an Environmentally Sustainable Tourism Industry. Journal of Travel Research, 38(3): 239-245.

Hong Kong Tourism Board (HKTB). (2011). Visitor Arrival Statistics. Retrieved May 3, 2011, from http://partnernet.hktb.com/pnweb/jsp/comm/index.jsp?charset=en.

Kim, S. S., Guo, Y., \& Agrusa, J. (2005). Preference and Positioning Analyses of Overseas Destinations by Mainland Chinese Outbound Pleasure Tourists. Journal of Travel Research, 44(2): 212-220.

Korea Tourism Organization (2011a). Key Facts on Tourism. Retrieved December 12, 2012 , from http://kto.visitkorea.or.kr/eng/tourismStatics/keyFacts/KoreaMonthlyStatistics.kto

Korea Tourism Organization (2011b). Attractions: Theme Travel. Retrieved June 7, 2011, from http://english.visitkorea.or.kr/enu/SI/SI_EN_3_4_0.jsp.

Li, G., Song, H., \& Witt, S. F. (2004). Modelling Tourism Demand: A Dynamic Linear AIDS Approach. Journal of Travel Research, 43(2): 141-150.

Li, G., Song, H., \& Witt, S. F. (2006). Time Varying Parameter and Fixed Parameter Linear AIDS: An Application to Tourism Demand Forecasting. International Journal of Forecasting, 22(1): 57-71.

Lyssiotou, P. (2000). Dynamic Analysis of British Demand for Tourism Abroad, Empirical Economics, 25(3): 421-436.

Macau Government Tourist Office (2011). Statistics \& Studies. Retrieved December 12, 2012, from http://industry.macautourism.gov.mo/en/index.php. 
Mangion, M., Durbarry, R., \& Sinclair, M. T. (2005). Tourism Competitiveness : Price and Quality. Tourism Economics, 11(1), 45-68.

Osmanagic-Bedenik, N. (1999). The Analysis of Business Efficiency of the Biggest Hotel and Tourism Companies in Croatia. Turizam, Special Issue on Competitiveness in Tourism and Hospitality, 47(4): 344-367.

Pao, J. (2004). Recent Developments and Prospects of Macao's Tourism Industry. Retrieved May 28, 2011, from http://www.amcm.gov.mo/publication/quarterly/Oct2004/Macao_en.pdf.

Papatheodorou, A. (1999). The Demand for International Tourism in the Mediterranean Region. Applied Economics, 31(5): 619-630.

Pechlaner, H. (1999). The Competitiveness of Alpine Destinations between Market Pressure and Problems of Adaptation. Turizam, Special Issue on Competitiveness in Tourism and Hospitality, 47(4): 332-343.

Prideaux, B. (2000). The Role of the Transport System in Destination Development. Tourism Management, 21(1): 53-64.

Ritchie, J. R., \& Crouch, G. I. (2003). The Competitive Destination: a Sustainable Tourism Perspective. CABI Publishing: Wallingford.

Song, H., Li, G., Witt, S. F., \& Fei, B. (2010). Tourism Demand Modelling and Forecasting: How should Demand be Measured? Tourism Economics, 16(1), 63-81.

Song, H., Wong, K. F., \& Chon, K. S. (2003). Modelling and Forecasting the Demand for Hong Kong Tourism. International Journal of Hospitality Management, 22(4), 435-451.

Song, H., \& Witt, S. F. (2000). Tourism Demand Modelling and Forecasting: Modern Econometric Approaches. Pergamon: Oxford.

Song, H., \& Witt, S. F. (2006). Forecasting International Tourist Flows to Macau. Tourism Management, 27, 214-224.

Syriopoulos, T., \& Sinclair, M. T. (1993). A Dynamic Model of Demand for Mediterranean Countries. Applied Economics, 25: 1541-1552.

Wong, E. P. Y., Bauer, T. G., \& Wong, K. K. F. (2008). A Critical Comparison of Tourism Policies of Hong Kong and Singapore - An Avenue to Mutual Learning. International Journal of Tourism Research, 10(3): 193-206.

Wu, D. C., Li, G., \& Song, H. (2011). Analyzing Tourist Consumption: A Dynamic System-ofEquations Approach. Journal of Travel Research, 50(1), 46-56.

Zellner, A. (1962). An Efficient Method of Estimating Seemingly Unrelated Regressions and Test for Aggregation Bias. The Journal of the American Statistical Association, 57(298): 348-368. 